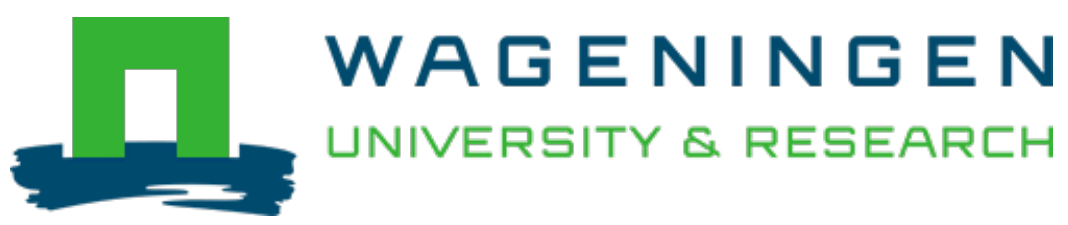

\title{
Household production of sorghum beer in Benin: technological and socio- economic aspects
}

International Journal of Consumer Studies

Kayodé, A.P.P.; Hounhouigan, J.D.; Nout, M.J.R.; Niehof, A.

https://doi.org/10.1111/j.1470-6431.2006.00546.x

This publication is made publicly available in the institutional repository of Wageningen University and Research, under the terms of article $25 \mathrm{fa}$ of the Dutch Copyright Act, also known as the Amendment Taverne. This has been done with explicit consent by the author.

Article 25 fa states that the author of a short scientific work funded either wholly or partially by Dutch public funds is entitled to make that work publicly available for no consideration following a reasonable period of time after the work was first published, provided that clear reference is made to the source of the first publication of the work.

This publication is distributed under The Association of Universities in the Netherlands (VSNU) 'Article $25 \mathrm{fa}$ implementation' project. In this project research outputs of researchers employed by Dutch Universities that comply with the legal requirements of Article $25 \mathrm{fa}$ of the Dutch Copyright Act are distributed online and free of cost or other barriers in institutional repositories. Research outputs are distributed six months after their first online publication in the original published version and with proper attribution to the source of the original publication.

You are permitted to download and use the publication for personal purposes. All rights remain with the author(s) and / or copyright owner(s) of this work. Any use of the publication or parts of it other than authorised under article $25 \mathrm{fa}$ of the Dutch Copyright act is prohibited. Wageningen University \& Research and the author(s) of this publication shall not be held responsible or liable for any damages resulting from your (re)use of this publication.

For questions regarding the public availability of this publication please contact openscience.library@wur.nl 


\title{
Household production of sorghum beer in Benin: technological and socio-economic aspects
}

\author{
A.P. Polycarpe Kayodé, ${ }^{1,2}$ D. Joseph Hounhouigan, ${ }^{1}$ Martinus J.R. Nout ${ }^{2}$ and Anke Niehof ${ }^{3}$ \\ ${ }^{1}$ Département de Nutrition et Sciences Alimentaires, Faculté des Sciences Agronomiques, Université d'Abomey-Calavi, Cotonou, Bénin \\ ${ }^{2}$ Laboratory of Food Microbiology, Wageningen University, Wageningen, the Netherlands \\ ${ }^{3}$ Social Sciences Group, Wageningen University, Wageningen, the Netherlands
}

\author{
Keywords \\ Gender, income, quality, sorghum beer, \\ tchoukoutou. \\ Correspondence \\ Martinus J.R. Nout, Laboratory of Food \\ Microbiology, Wageningen University, PO Box \\ 8129,6700 \\ EV Wageningen, the Netherlands. \\ E-mail: rob.nout@wur.nl
}

doi: 10.1111/j.1470-6431.2006.00546.x

\begin{abstract}
This study evaluated the sorghum brewing microenterprises in Benin with emphasis on the beer quality, the social significance of the product as well as the income generated. Tchoukoutou, the Benin opaque sorghum beer, has important social functions as it fosters the cooperative spirit and remains an ancestral beverage widely used for traditional ceremonies. The manufacturing process consists of malting (soaking, germination and sun drying), brewing (mashing, boiling, filtration) and fermentation. The beer is sour with a $\mathrm{pH}$ of 3.2 and contains a relatively high but variable level of solids and crude protein. Most of the consumers appreciate an opaque, sour and pink-coloured beer. The consumers related many of the beer properties to health effects. Participants can link the perceived qualities of the beer to the grain's functional properties, and this leads to the classification of the farmers' sorghum as varieties of top, medium and low quality for brewing. The profits from tchoukoutou production range from 2365 to $17212 \mathrm{fcfa}$ per month ( 1 euro $=656 \mathrm{fcfa}$ ) for the producers, depending on beer yield and quantity of raw grain transformed. The generated income is used for household needs and part of it is invested in children's education.
\end{abstract}

\section{Introduction}

Food insecurity persists in Sub-Saharan Africa and is partly due to inadequate food production. But more importantly, low household income and poverty limit people's access to the means to provide for their basic needs, particularly food. Seen in this way, food insecurity is a component of livelihood insecurity. Ellis (2000) defines livelihood as follows: 'A livelihood comprises the assets (natural, physical, human, financial and social capital), the activities, and the access to these (mediated by institutions and social relation) that together determine the living gained by an individual or household'. Men and women in developing countries tend to diversify their livelihood activities, sources of income and asset base to enhance their livelihood and food security. Women's income generating activities in developing countries often significantly contribute to the household income (Niehof, 2004). From her work in eastern Zambia, Peterson (1999) recorded 25 income generating activities of farmers (women and men). These were categorized by the farmers as either 'small-money' activities, 'medium-size money' activities, or 'big-money' activities, depending on the level of income generated by these activities and their contribution to livelihood sustainability. Women were especially engaged in 'small-money' and 'medium-sized money' activities, which mainly included selling raw and locally processed crop foods such as porridge, fritters and beverages. West African women have a long and well-documented record of entrepreneurship (Mandel, 2004). They are active in food-processing microenterprises that play an important role in the local economy. The foods produced by these artisanal structures, usually referred to as 'street foods', significantly contribute to the food supply of the local - particularly the low-income - population because they are cheap and easily accessible (Ekanem, 1998).

Opaque sorghum beer, a street food product, is a popular alcoholic beverage in the northern Guinea Savannah region of West Africa. It is known as tchoukoutou in Benin and by various other names in other parts of West Africa (Odunfa, 1985; Kayode et al., 2005). It has a sour taste, a relatively high dry matter content (5$13 \%)$ and low alcohol content (2-3\%), which makes it a suitable beverage for adults and teenagers (Agu and Palmer, 1998; Briggs et al., 2004). It is largely consumed by the poorest, and significantly contributes to the diets of millions of people and generates income for the women sellers who produce it at household level, using the traditional technology. The beer is originally prepared with sorghum (Guinea corn; Sorghum bicolor), but other starch sources like millet or maize can be used as adjuncts or as substitutes (Kayode et al., 2005). In some cases as much as $30 \%$ of sorghum harvested in Africa is used for malting and brewing (Nout, 1980). The manufacturing process consists of soaking, 
germination, sun drying, mashing, boiling and fermentation. Depending on the geographic location variations may occur in the process (Odunfa, 1985; Haggblade and Holzapfel, 1989).

The objectives of the present study are threefold. First, to examine the social significance of sorghum beer; second, to evaluate the quality of the product in terms of consumers' perception, nutrient content and microbiological safety; and third, to quantify the income generation potential of sorghum brewing microenterprises in Benin and their contribution to household livelihood security.

\section{Methodology}

\section{Survey}

The field research was conducted in northern Benin and took place in two stages. First, interviews were held with 135 sorghum beer processors and consumers in three communities with a rich beerbrewing tradition, namely Natitingou, Djougou and Parakou. The questionnaire included the following aspects:

- frequency of consumption: frequently $=4-7$ times/week, regularly $=2-3$ times/week, occasionally $=1$ time/week and rarely $=$ less than 1 time/week.

- quality perception: consumers gave their opinions on the importance of the quality traits of the product, that is, appearance, taste, colour and smell. Finally, we recorded consumers' opinions on the suitability of sorghum varieties for beer making.

Interviews with $10 \mathrm{key}$ informants were performed to assess the social significance of the product. These informants were senior and highly experienced processors, who had been recruited on the basis of recommendations by extension workers and fellow villagers. Data were analysed using Winstat 2.0 software.

The second stage of the field research was a case study performed in Parakou, involving three beer processors. Processor 1 (P1) is the head of a group of eight beer processors. They produce beer every 2 days to meet consumers' demand. P2 works in association with another processor and they produce tchoukoutou twice a week, while P3's brewery is a family business which produces beer once a week. Three batches of red sorghum grain were selected and purchased by the processors at the local market and were processed into beer at the three respective commercial production sites following their traditional brewing practices. At the end of the fermentation process, beer samples were collected in sterile screw-capped bottles, packed in a thermo-cooler containing crushed ice, transported to the laboratory, and immediately analysed for $\mathrm{pH}$, titratable acidity and microbiological characteristics. The processors were observed while carrying out the brewing operations. Quantitative data were collected on inputs (raw material, labour, money, equipments, water, fuel and time) and outputs (yield, by-products and sales).

The protocols used for the quantitative survey and the case study were approved by the Faculty of Agronomical Science of the University of Abomey-Calavi; informed consent was obtained from all respondents.

\section{Microbiological analysis}

Total counts of mesophilic aerobic bacteria, lactic acid bacteria (LAB), yeasts, moulds and Enterobacteriaceae were enumerated according to the method described by (Nout et al., 1987).

\section{Physico-chemical analysis}

Crude protein $(\mathrm{N} \times 6.25)$, dry matter and ash contents were determined according to American Association of Cereal Chemistry (AACC) methods (AACC, 1984). $\mathrm{pH}$ and titratable acidity were determined as described by Nout et al. (1989).

\section{Results and discussion}

\section{The social significance of sorghum beer consumption}

In the study areas, two kinds of sorghum beer were identified: tchoukoutou and chakpalo. They have different appearance and taste. Chakpalo is a clear and sweet fluid, while tchoukoutou is an opaque (turbid) and acidic beer. Table 1 shows the consumption patterns for the different sorghum beers per region. Tchoukoutou is the most frequently consumed beer in the study regions. The frequency of consumption is higher in Natitingou and Djougou, probably because these places are the cultural origin of this beer. In Parakou both beers are consumed with a relatively high frequency. This is most likely related to the ethnic diversity in this city, which is also regarded as a crossroad of various communities.

The relationship between gender and the frequency of consumption is found to be significant (Table 2): tchoukoutou is mostly consumed by men. The beer is regarded as a stimulant, especially when people want to accomplish energy-demanding work; 'tchoukoutou donne la force', as many like to say (Van Liere, 1993).

Apart from its role as a beverage, tchoukoutou also has an important social function. In the northern Benin regions, a market day without tchoukoutou is unthinkable. Due to the higher demand

Table 1 Frequency of consumption of sorghum beers in three communities in northern Benin (in percentage of respondents)

\begin{tabular}{|c|c|c|c|c|c|c|}
\hline \multirow[b]{2}{*}{ Frequency ${ }^{a}$} & \multicolumn{3}{|c|}{ Tchoukoutou } & \multicolumn{3}{|l|}{ Chakpalo } \\
\hline & $\begin{array}{l}\text { Parakou } \\
(n=45)\end{array}$ & $\begin{array}{l}\text { Natitingou } \\
(n=45)\end{array}$ & $\begin{array}{l}\text { Djougou } \\
(n=45)\end{array}$ & $\begin{array}{l}\text { Parakou } \\
(n=45)\end{array}$ & $\begin{array}{l}\text { Natitingou } \\
(n=45)\end{array}$ & $\begin{array}{l}\text { Djougou } \\
(n=45)\end{array}$ \\
\hline Frequently & 20 & 52 & 47 & 18 & 0 & 0 \\
\hline Regularly & 4 & 24 & 22 & 16 & 2 & 0 \\
\hline Occasionally & 16 & 11 & 0 & 35 & 0 & 4 \\
\hline Rarely & 60 & 13 & 31 & 31 & 98 & 96 \\
\hline
\end{tabular}

aFrequently: 4-7 times/week; regularly: 2-3 times/week; occasionally: 1 time/week; rarely: less than 1 time/week. 
Table 2 Tchoukoutou consumption by gender

\begin{tabular}{llcccc}
\hline & Frequently & Regularly & Occasionally & Rarely & Total \\
\hline Male & $27(60 \%)$ & $9(20 \%)$ & $2(4.4 \%)$ & $7(15.6 \%)$ & $45(100 \%)$ \\
Female & $26(29 \%)$ & $14(15.6 \%)$ & $10(11 \%)$ & $40(44.4 \%)$ & $90(100 \%)$ \\
Total & $53(39.3 \%)$ & $23(17 \%)$ & $12(8.9 \%)$ & $47(34.8 \%)$ & $135(100 \%)$ \\
\hline
\end{tabular}

${ }^{a} \chi^{2}$ is significant at 0.01 level.

and appreciation of consumers, tchoukoutou pubs are encountered in almost all neighbourhoods. Special tchoukoutou markets are also held in some regions. For example, Kilombo and Chakatabam are very popular tchoukoutou markets in Parakou. These markets are held weekly and attract many customers. A tchoukoutou market is a place where people socialize and information and experiences are shared. At the neighbourhood level, the ambiance created by tchoukoutou is intense, particularly during weekends when paten'ti is organized. Paten' $t i$ is a special event organized on Friday and Saturday nights around the tchoukoutou pot. It involves the tchoukoutou processors, a disc jockey, consumers and (female) sellers of fruits, sweets, cooked rice and kpakuman (cooked beef skin). The chief organizer of the Paten'ti is the tchoukoutou processor who pays for hiring the music accessories. Sometimes it is the best rendezvous place for young men and women as tchoukoutou also makes them feel free to express their thoughts.

Tchoukoutou is an ancestral beverage widely used for traditional ceremonies such as weddings, baptism, excision (not practised anymore nowadays), circumcision, 'tatouage', burial ceremonies and zolari (annual popular sorghum feast in Djougou region). It is indispensable for the farm labour force as the beer fosters a cooperative spirit.

\section{Sorghum beer processing}

Tchoukoutou is produced by women using various processes. In general, as in the conventional lager beer process, the method consists of three phases: malting, mashing and fermentation. On average, $27 \mathrm{~kg}$ (referred to as one winnere: the local name of the basket used to measure the grains) of grain is processed in one batch. The grain is soaked in water overnight (9-12 h), germinated ( $72-85 \mathrm{~h})$, sun dried (7-15 h), ground in a disc mill, mixed with water, decanted and divided into slurry and supernatant. The slurry is mashed by gradual heating until the boiling point is reached after $2 \mathrm{~h}$, mixed with supernatant and allowed to sour during overnight fermentation, filtered, boiled (6-9 h), cooled, inoculated with a starter (called kpetekpete) harvested from the previous batch and fermented overnight (13-14 h).

The choice of the type of sorghum is crucial as it will determine, together with other factors, the success of the beer brewing. Processors often claim that not all sorghum varieties are suitable for beer production. The storage duration of the grain is an important criterion to which processors pay special attention when choosing the grain for brewing, particularly in the period of SeptemberDecember, when the grains have been stored for longer than 6 months. Insect damage to the grain, detectable by the presence of holes or floury dust, is an efficient indicator that grains have become unsuitable for brewing. Other important selection factors for brewing sorghum include: size and colour of the grain, wort quantity and quality (mainly sugar content) and to a lesser extent the origin of the grain (Kayode et al., 2005).

Kayode et al. (2005) identified many farmers' varieties of sorghum in northern Benin and grouped them according to their ability to yield a good quality beer. The first category comprises the varieties that are very good for brewing, including chabicouma, chassisoya and agbani. The first-rate varieties are generally used as a reference by which to judge the other varieties. They are brown, floury and have big grains. They give a high yield of wort with very good properties, that is, sugary and opaque. Generally, processors use the wort properties as an indicator of the quality of the beer, the sweetness being the major criterion. The sweeter the wort is, the better the beer will be. Another advantage of these varieties is their relatively high availability, presumably due to some favourable agronomic properties. After storage, all of them are still good for brewing as they germinate well. Moreover, they yield well with soils that have a low fertility and some (chassisoya) are resistant to Striga, an obligate parasitic plant that attacks the roots of agronomically important crops, including sorghum. Second-rate varieties are: wawira, soniya, mousseman, mouhoulouman, talemoula and fissouka. These varieties are also suitable for tchoukoutou processing, although some factors limit their utilization. The white colour of some (e.g. mouhoulouman, talemoula) is not favoured for beer processing. These varieties are always mixed with red sorghum otherwise the beer would become too white; consumers prefer pink/red beer because they believe coloured beer is healthy (Kayode et al., 2005). Other varieties are too hard and thus prolong the processing time. This is the case with soniya and wawira which require 2-3 days of soaking time instead of 1 , prior to germination. In addition, more inoculum is needed for a quick fermentation of their wort. Finally, the third group comprises the varieties unsuitable for brewing. These are sotakama, kassassahan, kangnanra (yellow varieties) and natisoya. The main shortcoming of natisoya is that it yields a less sugary wort. Another limitation is that it loses its germinative power after a short storage period. However, because it is an early maturing variety some processors used it, just after harvesting, to produce a beer of 'bad quality' as they say.

Tchoukoutou production is not a highly labour-intensive activity but it takes a long time (Table 3). Seven to 10 days are required to complete a process cycle. Given this constraint and also because of the investment needed, processors usually team up in groups to fulfil the consumers' demand. This kind of association is mostly based on family relationships. For instance, P1 belongs to a group of eight processors, and P2 associated with a friend from her village to be able to produce beer twice a week. P1 is the head of the group and has invested in the main process equipments. Her two daughters, two sisters and three friends from her village are the members of her group. P1 was previously a member of a group 
Table 3 Time duration (h) for sorghum grain processing into tchoukoutou

\begin{tabular}{|c|c|c|c|c|c|c|}
\hline Unit operation & $\begin{array}{l}\mathrm{P} 1 \\
(25 \mathrm{~kg})\end{array}$ & $\begin{array}{l}\mathrm{P} 2 \\
(31 \mathrm{~kg})\end{array}$ & $\begin{array}{l}\text { P3 } \\
(27 \mathrm{~kg})\end{array}$ & Average & $\begin{array}{l}\text { Working } \\
\text { hours (h) }\end{array}$ & $\begin{array}{l}\text { Labour }^{\mathrm{a}} \text { demand } \\
\text { (full-time equivalent }-\mathrm{fte} \text { ) }\end{array}$ \\
\hline Soaking & 11 & 9 & 13 & 11 & 2.0 & 0.25 \\
\hline Pregermination & 13 & 13 & 24 & 17 & 0.5 & 0.06 \\
\hline Germination & 72 & 61 & 48 & 60 & 4.0 & 0.50 \\
\hline Drying & 16 & 15 & 7 & 12 & 3.0 & 0.38 \\
\hline Milling & 0.25 & 0.25 & 0.25 & 0.25 & 0.25 & 0.03 \\
\hline Suspending/settling & 1 & 1 & 1 & 1 & 1.0 & 0.13 \\
\hline Boiling/saccharification & 1.75 & 1.25 & 1.75 & 1.5 & 1.5 & 0.19 \\
\hline First fermentation/saccharification & 12.5 & 10 & 12.75 & 12 & 1.0 & 0.13 \\
\hline Filtering & 3 & 0.5 & 0.5 & 1.3 & 0.75 & 0.09 \\
\hline Boiling & 9.5 & 8.0 & 6.5 & 8.0 & 5.0 & 0.63 \\
\hline Cooling & 2.75 & 2.5 & 2.5 & 2.5 & 0.5 & 0.06 \\
\hline Second fermentation & 13.0 & 14.0 & 13.0 & 13.3 & 1.5 & 0.19 \\
\hline Total & 155.75 & 135.5 & 130.25 & 139.85 & 21.0 & 2.63 \\
\hline
\end{tabular}

${ }^{\mathrm{a}} 1 \mathrm{fte}=8$ working hours.

Table 4 Consumers' quality preferences for sorghum beers ( $\%$ of respondents ${ }^{a}$ )

\begin{tabular}{|c|c|c|c|c|c|c|c|c|c|c|}
\hline & \multicolumn{2}{|c|}{ Appearance } & \multicolumn{5}{|l|}{ Taste } & \multicolumn{3}{|c|}{ Colour } \\
\hline & Opaque & Clear & Very sweet & Sweet & Neutral & Acidic & Very acidic & Pink & Red & White \\
\hline Tchoukoutou $(n=82)$ & 86 & 14 & 4 & 16 & 7 & 100 & 22 & 88 & 78 & 3 \\
\hline Chakpalo $(n=24)$ & 6 & 69 & 30 & 97 & 0 & 40 & 0 & 96 & 100 & 0 \\
\hline
\end{tabular}

${ }^{\text {aSum }}>100$ because several answers were possible.

$\mathrm{n}$, number of people interviewed on the beverage for the quality aspects.

directed by the wife of her older brother. From this group she gained the knowledge of brewing and part of the money used to purchase her own equipments. Because of her accrued experience she supervises the process and the other members usually refer to her for advice. Each processor in the group has her turn in such a way that when someone is at the germination step, another one is soaking for a new processing cycle. The processing takes place at the household level, usually at the home of the head of the group who manages the space for processing. Typically a brewing 'enterprise' includes a sprouting area $\left(6-10 \mathrm{~m}^{2}\right.$ ) (in some cases a space is arranged in the sleeping room for sprouting), and a kitchen with provisions for the use of big pots. The family kitchen is usually situated next to the brewing kitchen. Another kind of social organization of beer production is represented by processor (P3), where beer is exclusively produced by the family, that is, the mother and her daughters or other close relatives who may have their own occupations (e.g. going to school, farming, selling small necessities) but occasionally help their mother in brewing.

There is some ethnic specialization related to brewing activities. Like most of the tchoukoutou brewers in Parakou, the three processors observed originated from the north-western part of Benin where tchoukoutou is believed to have come from. Chakpalo is exclusively brewed by Idatcha women from the central part of the country, where this beer is believed to have originated.

\section{Quality as perceived by consumers}

Consumers expressed a strong preference for tchoukoutou compared with chakpalo and clearly differentiated between both beers in terms of quality attributes (Table 4). Most consumers prefer an opaque tchoukoutou. The beverage should be acidic with a colour ranging from pink to reddish. To the question 'why do you prefer these specific quality attributes?' consumers give diverse answers. Some argue that opaque beer appeases hunger. The reasons for drinking brown or reddish beer are health-related beliefs. Because it is a general belief that beer brewed from maize (a white beer) causes headache, consumers indicated that the pink colour of a beer guarantees that it was brewed from sorghum.

Another important quality aspect of tchoukoutou is the alcohol content. A beer with high alcohol content is preferred. Actually the alcohol content of opaque sorghum beer ranges between $2 \%$ and 3\% (Agu and Palmer, 1998; Briggs et al., 2004). But considering the relatively big volume of beer consumed daily, consumers can ingest considerable quantities of alcohol. During the harmattan season (a cold period) the authors observed some consumers adding sodabi (a local distilled alcohol) to tchoukoutou to make it more powerful, as they say. The odour of the beer is also perceived as an important attribute by some consumers. Some consumers claim to be able to infer the overall quality of tchoukoutou by its odour (Kayode et al., 2005). Finally, a minority of consumers appreciate a bitter beer because they believe that such beer 'fights against malaria' and 'cleans the blood'.

To meet consumers' quality demands, processors make use of certain food-processing practices. To produce bitter beer, the yellow varieties (bitter varieties) are used as hops would be used in a European lager beer. For this purpose, grains are either crushed with the malt or the ears of bitter varieties are immersed in the wort during cooking. Other processors grind them after the grain is 
roasted. The flour obtained is then stored and added to the wort during cooking. A larger mesh basket or bag is used to permit the infiltration of suspended solid matter to enhance the opacity of the beer. From the opacity point of view, consumers distinguished two kinds of tchoukoutou. Kotouman, a very opaque tchoukoutou, is perceived as different from chololo (relatively less opaque tchoukoutou). The use of a sticky solution, obtained from a watery extraction of the bark of sarikibou (a wild tree) during the decantation process is responsible for the lesser opacity of chololo. Indeed, sarikibou is used to accelerate the decantation process. As it contributes to the precipitation of small solid particles, it contributes to a better filtration. The alcohol content of tchoukoutou is produced by yeasts (Nout, 1980; Sefa-Dedeh et al., 1999). Here the inoculum (kpetekpete) used - kept in a calabash - consists of yeasts harvested from a previous batch. The microorganisms are kept alive by replacing the supernatant on a daily basis. When we asked a processor what would happen if the water was not regularly renewed for the inoculum, she replied: 'kpetekpete looses its strength and will not make the beer effervescent anymore', meaning that the yeasts would have died.

\section{Microbiological quality}

Tchoukoutou is a sour beverage with a $\mathrm{pH}$ of $3.2 \pm 0.2$, and a titratable acidity of $0.8 \pm 0.1$ (in percentage lactic acid equivalent). The product contains a relatively high but variable level of solids and crude protein. The major microorganisms involved in the fermentation of the beverage are LAB and yeasts (Table 5). The $\mathrm{LAB}$ produce lactic acid and other organic acids lowering the $\mathrm{pH}$ of the product from about 6.5-3.6 (Hounhouigan et al., 1993). If the $\mathrm{pH}$ of a food product is below 4.0, the growth of diarrhoea causing pathogens is inhibited (Nout et al., 1989; Motarjemi and Nout, 1996). Consequently, it can be argued that beverages like tchoukoutou are less likely to be a source of pathogenic bacteria and are safe, even under conditions of poor hygiene. Our result confirms this as the Enterobacteriaceae family of bacteria are below detection level in the product $(\log \mathrm{cfu} / \mathrm{ml}<1)$. Indeed, consumers rarely complain about stomach troubles or diarrhoea after consuming tchoukoutou. By contrast, chakpalo is fermented to a lesser extent, and frequent stomach pains resulting from its consumption are an important factor in its lesser popularity.

Table 5 Nutritional and microbiological attributes of tchoukoutou

\begin{tabular}{|c|c|c|c|}
\hline & Processor 1 & Processor 2 & Processor 3 \\
\hline \multicolumn{4}{|c|}{ Physico-chemical attributes } \\
\hline Crude protein (\% dm) & 3.7 & 7.9 & 6.8 \\
\hline Dry matter (\% wb) & 13.5 & 12.1 & 4.8 \\
\hline Refractive index (\%) & 17.5 & 14.0 & 7.0 \\
\hline $\mathrm{pH}$ & 3.0 & 3.4 & 3.1 \\
\hline $\begin{array}{r}\text { Titratable acidity } \\
\text { (\% lactic acid) }\end{array}$ & 0.5 & 0.8 & 0.6 \\
\hline \multicolumn{4}{|c|}{ Microbiological attributes (Log cfu/ml) } \\
\hline Total count & nd & 8.2 & 7.8 \\
\hline Yeasts & 8.5 & 7.9 & 7.8 \\
\hline Lactic acid bacteria & nd & 7.9 & 7.6 \\
\hline Enterobacteriacae & $<1$ & $<1$ & $<1$ \\
\hline
\end{tabular}

dm, dry matter; nd, not determined; wb, wet basis.

\section{Hygienic quality}

The hygiene of sorghum beer processing practices may have important health risk implications for the consumers. Extensive growth of moulds was observed on the sprouted grains after 3 days of germination. These fungi may include Aspergillus spp., a genus harbouring mycotoxigenic species encountered in the study areas (Setamou et al., 1997). Aflatoxins are quite stable and when present in malted grain, they may persist in the beer.

\section{Yields and profits}

The yield of tchoukoutou beer, shown in Table 6, varied from 170 to 4561 with an average of 2821 per $100 \mathrm{~kg}$ of dry grain. In terms of dry mass balance, an average $24 \%$ of the total processed grain is recovered in the beer.

Dilution with water is the main factor explaining the large variation observed in beer yield. This is further confirmed by the input quantification (Table 7) which showed that P3, with the highest beer yield, makes use of the largest quantity of water; almost twice the quantity as used by P1 who had the lowest beer yield. The boiling time is also likely to correlate with the yield, with longer boiling resulting in lower yield. As can be observed from Table 6, the average beer yield on dry matter basis is $24 \%$ which is quite low. The most important losses of dry matter occurred during the germination (10-19\%), mashing/filtration (27-44\%) and the second filtration after the fermentation (12$39 \%$ ). Spent grain (residue) is valorized as animal feed. In most cases, sorghum processors rear pigs that are fed with the byproducts. The animals are sold to generate income. The yield of the beer is linkable to its quality, and this determines the price of the product.

Table 7 shows that the beer from P1 is the most expensive $(355 \mathrm{fcfa} / \mathrm{kg} ; 1$ euro $=656 \mathrm{fcfa})$. One litre of beer 1 is at least twice as expensive as beer 3 . Indeed, beer 1 meets consumer preferences best (Table 4) because of its high opacity, high acidity and probably high alcohol content (see Table 5).

The profitability of the three processes was estimated taking into account the different inputs and outputs. The calculation was done for each individual processor on a monthly basis assuming four processing cycles per month. Even though the processors

Table 6 Mass balance of tchoukoutou processing (kg dry matter)

\begin{tabular}{lccc}
\hline & Processor 1 & Processor 2 & Processor 3 \\
\hline Raw grain & 100 & 100 & 100 \\
Soaked & 92 & 95 & 98 \\
Germinated & 79 & 76 & 88 \\
Mashed/filtred & 35 & 48 & 61 \\
Boiled & 35 & 45 & 53 \\
Fermented/filtred & 23 & 27 & 22 \\
Beer yield (I) & 170 & 220 & 456 \\
Beer dm content (\%) & 13.5 & 12.1 & 4.8 \\
Beer yield (kg dm) & 23 & 27 & 78 \\
Spent grains (kg dm) & 77 & 73 & ( 322 \\
\hline
\end{tabular}

a Volume of beer obtained per $100 \mathrm{~kg}$ of dry raw grain; bry matter content of the beer. 
Table 7 Estimated cost, gross margins and net processing margins of tchoukoutou production per month

\begin{tabular}{|c|c|c|c|c|c|c|c|c|c|}
\hline \multirow[b]{2}{*}{ Item } & \multicolumn{3}{|c|}{ Price (fcfa/kg) } & \multicolumn{3}{|c|}{ Quantity (kg) } & \multicolumn{3}{|c|}{ Value $(f c f a)^{*}$} \\
\hline & $\mathrm{P} 1$ & $\mathrm{P} 2$ & P3 & $\mathrm{P} 1$ & $\mathrm{P} 2$ & P3 & $\mathrm{P} 1$ & $\mathrm{P} 2$ & P3 \\
\hline \multicolumn{10}{|l|}{ Input } \\
\hline \multicolumn{10}{|l|}{ Variable cost } \\
\hline Sorghum grain & 88 & 65.15 & 74 & 100 & 122.8 & 108 & 8834 & 8000 & 8003 \\
\hline Water & 1.47 & 1.47 & 1.47 & 564 & 793.6 & 1054 & 829 & 1167 & 1549 \\
\hline Fuel & & & & & & & 8000 & 8000 & 8000 \\
\hline Milling & 15 & 11.7 & 14 & 80 & 102.4 & 112 & 1200 & 1198 & 1602 \\
\hline Total variable cost (a) & & & & & & & 18863 & 18365 & 19154 \\
\hline \multicolumn{10}{|l|}{ Fixed costs } \\
\hline \multicolumn{10}{|l|}{ Depreciation charges } \\
\hline Durable equipments ${ }^{a}$ & & & & & & & 745 & 630 & 567 \\
\hline Small equipments ${ }^{\mathrm{b}}$ & & & & & & & 283 & 475 & 158 \\
\hline Processor salary/month ${ }^{c}$ & & & & & & & 30000 & 30000 & 30000 \\
\hline Total fixed cost (b) & & & & & & & 31028 & 31105 & 30725 \\
\hline \multicolumn{10}{|l|}{ Output } \\
\hline Gross output/month ${ }^{d}$ & 355 & 276 & 155 & 147.2 & 241.6 & 468 & 52256 & 66682 & 72540 \\
\hline Selling out (\%) & & & & 100 & 100 & 80 & & & \\
\hline Gross output/month ${ }^{\mathrm{d}}$ (c) & 355 & 276 & 155 & 147.2 & 241.6 & 374.4 & 52256 & 66682 & 58032 \\
\hline \multicolumn{10}{|l|}{ Profitability } \\
\hline Gross margin/month $(c-a)$ & & & & & & & 33393 & 48317 & 38878 \\
\hline Net processing margin/month $c-(a+b)$ & & & & & & & 2365 & 17212 & 8153 \\
\hline
\end{tabular}

a Durable equipments are: basin, buckets, pot, jar, mortar and pestle. Their depreciation charge is calculated on the basis of 5 years life duration; ${ }^{b}$ Small process equipments are: calebashes, basket, polythene bags, oilclothes, siever, mixing device. Their depreciation charge is calculated on the basis of 6 months life duration; ' $T$ The salary is attributed on the basis of SMIG (official minimum wages) which is $27000 \mathrm{fcfa}$; ${ }^{\mathrm{d}}$ Assuming four processing cycles in a month.

${ }^{*} 1 €=656$ fcfa.

P1, P2, P3 denote processor 1, processor 2 and processor 3 respectively.

don't attribute wages to themselves, the authors did so to each of them on the basis of the Benin minimum wages in order to measure labour costs. Apart from the raw grain, the most expensive input in tchoukoutou processing is the fuel, which alone makes up to $43 \%$ of the total variable cost. A lot of wood is used during the boiling process which lasts the whole day. Among the foodprocessing activities in the study area, tchoukoutou making probably consumes the most firewood. There is some evidence that these practices are a threat to forest preservation. The net processing margin from tchoukoutou production is in the range of 2365-17 212 fcfa per month, and the profits depend on beer yield and quantity of raw grain transformed (Table 7). It is noteworthy that P3 with the highest beer yield didn't generate the highest profit because the excessive dilution of the beer fetched a low sales price and of the beer, only $80 \%$ could be sold. Leftovers are served free to friends or relatives, or are enriched with starchy ingredients, fermented again and distilled to yield sodabi (strong alcoholic liquor). The money generated by the process is the property of the processor who conducted the brewing. In case of group production, each member pays the person who has provided the equipment (the head) an amount of $200 \mathrm{fcfa}$ as a contribution to the equipments depreciation. The money gained is used for different purposes. Primarily, it is used for meeting the basic needs of the family, that is, food and clothing. Usually, part of it is regularly - often weekly - deposited in an account with a 'tontinier' (ambulant banker). Generally, this 'tontine' - deposit account - lasts no longer than a year. The money can be with- drawn whenever needed, such as in case of emergencies like illness or burial ceremonies of relatives. Another important reason for saving money is to be able to finance children's education. For example, P1, whose husband has died years ago, paid for the sewing lessons of her daughter while P2 invests in her son's school fees. In this way and following the classification of Peterson (1999), tchoukoutou brewing can be regarded as a 'mediumsize money' activity.

\section{Conclusion and perspectives}

The brewing of traditional beer, tchoukoutou, is an important activity for West African rural women to diversify their household's livelihood portfolio. The microenterprises are generally profitable, providing jobs and income to many rural women in northern Benin. The product is gaining interest and the brewing activity has expanded beyond its area of origin. Tchoukoutou brewers are increasingly active in major cities of Benin. We foresee further expansion in the future. Beer brewing is clearly a gendered activity. First, the cultivation of the raw ingredient, sorghum, is based on a gendered division of labour with women being responsible for sowing and harvesting. Second, women transform it into beer and sell it. Men drink it, while women gain money to sustain their household's livelihood. This clearly demonstrates the prominent role of women in the economic cycle of this crop product. While income generation by women not necessarily leads to their empowerment, because that depends also on women's 
control over the allocation of the money generated (Ardener, 1995), the cases discussed here show that some processors invest the money they earn into their children's education. Furthermore, they are the ones who deposit the money with the 'tontinier' and decide on when to draw it out and for what purpose. In this way, the economic activities of the processors contribute to meeting women's strategic gender needs, not just their practical gender needs that only relate to sustaining their family and child care (Moser, 1994). Research in a fishing village in Indonesia has shown that when women play an important role in the local economy (in this case as fish traders and fish processors) they also have a strong social position and decision-making power beyond the domestic domain (Niehof et al., 2005).

Both 'etic' and 'emic' approaches were applied to apprehend the significance of the beer quality. 'Emic' refers to a 'logicoempirical system whose phenomenal distinctions are built up out of contrasts and discriminations, significant, meaningful, real, accurate, or in some other fashion regarded as appropriate by the actors themselves', 'etic' to 'phenomenal distinctions judged appropriate by the community of scientific observers' (our italics) (Harris, 1968). In the emic statements, consumers related many of the beer properties to health effects. The beliefs that 'bitter beer cleans the blood and fights against malaria', 'pink beer is healthy', or 'sweet beer can result in stomach pains', form altogether an emic representation of the product, based on long-term experience with sorghum cultivation and processing and consumption of the product. Interestingly, the producers and consumers could link the perceived qualities to functional properties of the grain, yielding an emic classification of the farmers' sorghum varieties as being of top, medium or low quality for brewing. In the etic perspective it was possible to document quality aspects of the sensorial and nutritional quality of the beer. Etic and emic approaches occasionally match well; for instance, the high consumers' preferences for opaque beer and the relation of this attribute to hunger appeasement are confirmed by the laboratory analyses which revealed the relatively high dry matter (nutrient) content of the desired product. In view of the selection of functional sorghum varieties for quality, health and well-being, further research and merging anthropological and life science data will be needed to discover relations between emic aspects and measurable attributes. The results of such research can guide the selection and breeding of sorghum varieties.

\section{Acknowledgements}

Financial support provided by Wageningen University through the North-South Interdisciplinary Research and Education Fund (INREF) is gratefully acknowledged. The International Foundation for Science, Stockholm, Sweden is acknowledged for financial support to A.P.P. Kayodé (Grant No. IFS E/3736-1).

\section{References}

AACC (1984) Approved Methods of the American Association of Cereal Chemistry. American Association of Cereal Chemistry, St. Paul, MN.

Agu, R.C. \& Palmer, G.H. (1998) A reassessment of sorghum for lagerbeer brewing. Bioresearch Technology, 66, 253-261.
Ardener, S. (1995) Women making money go round: ROSCAs revisited. In Money-Go-Rounds: the Importance of Rotating Savings and Credit Associations for Women (ed. by S. Ardener \& S. Burman), pp. 1-21. Berg, Oxford, Washington, DC.

Briggs, D.E., Boulton, C.A., Brookes, P.A. \& Stevens, R. (2004) Native African beers. In Brewing Science and Practice (ed. by R. Stevens), pp. 589-605. CRC Press, Woodhead Publishing Ltd, Boca Raton, FL, Cambridge.

Ekanem, E.O. (1998) The street food trade in Africa: safety and socioenvironmental issues. Food Control, 9, 211-215.

Ellis, F. (2000) Rural Livelihoods and Diversity in Developing Countries, Oxford University Press, Oxford.

Haggblade, S. \& Holzapfel, W.H. (eds) (1989) Industrialization of Africa's Indigenous Beer Brewing. Marcel Dekker, Inc, New York, Basel.

Harris, M. (1968) The Rise of Anthropological Theory. Thomas Y. Crowell Company, New York.

Hounhouigan, D.J., Nout, M.J.R., Nago, C.M., Houben, J.H. \& Rombouts, F.M. (1993) Changes in the physico-chemical properties of maize during natural fermentation of mawe. Journal of Cereal Science, 17, 291300 .

Kayode, A.P.P., Adégbidi, A., Linnemann, A.R., Nout, M.J.R. \& Hounhouigan, D.J. (2005) Quality of farmer's varieties of sorghum and derived foods as perceived by consumers in Benin. Ecology of Food and Nutrition, 44, 271-294.

Mandel, J.L. (2004) Mobility matters: women's livelihood strategies in Porto-Novo, Benin. Gender, Place and Culture, 11, 257-287.

Moser, C.O.N. (1994) Gender Planning and Development: Theory, Practice and Training. Routledge, London, New York.

Motarjemi, Y. \& Nout, M.J.R. (1996) Food fermentation: a safety and nutritional assessment. Bulletin of the World Health Organization, 74, 553-559.

Niehof, A. (2004) The significance of diversification for rural livelihood systems. Food Policy, 29, 321-338.

Niehof, A., Jordaan, R.E. \& Santoso, A. (2005) Technological and social change in a Madurese fishing village (1978-2004). Bijdragen Tot de Taal-, Land- En Volkenkunde, 161-4, 397-433.

Nout, M.J.R. (1980) Microbiological aspects of the traditional manufacture of busaa, a Kenyan opaque maize beer. Chemie Mikrobiologie Technologie der Lebensmittel, 6, 137-142.

Nout, M.J.R., Beernink, G. \& Bonants-Van Laarhoven, T.M.G. (1987) Growth of Bacillus cereus in soyabean tempeh. International Journal of Food Microbiology, 4, 293-301.

Nout, M.J.R., Rombouts, F.M. \& Havelaar, A. (1989) Effect of accelerated natural lactic fermentation of infant food ingredients on some pathogenic micro-organisms. International Journal of Food Microbiology, 8 , 351-361.

Odunfa, S.A. (1985) African fermented foods. In Microbiology of Fermented Foods (ed. by B.J.B. Wood), pp. 167-195. Elsevier Applied Science, London.

Peterson, J.S. (1999) Ethnographic decision trees and improved fallows in the Eastern Province of Zambia. Gender and Soil Fertility in Africa Collaborative Research Support Program and the International Centre for Research on Agroforestry, Gainesville, FL.

Sefa-Dedeh, S., Sanni, A.I., Tetteh, G. \& Sakyi-Dawson, E. (1999) Yeasts in the traditional brewing of pito in Ghana. World Journal of Microbiology and Biotechnology, 15, 593-597.

Setamou, M., Cardwell, K.F., Schulthess, F. \& Hell, K. (1997) Aspergillus flavus infection and aflatoxin contamination of preharvest maize in Benin. Plant Disease, 81, 1323-1327.

Van Liere, M.J. (1993) Coping with Household Food Insecurity: a Longitudinal and Seasonal Study Among the Otammari in North-western Benin. Wageningen University, Wageningen. 